\title{
"BOJ ZA ZNANJE BO V 21. STOLETJU HUJŠI, KOT JE BIL NEKOČ BOJ ZA OZEMLJA“ Umrl je profesor Dušan Savićević
}

Slab mesec dni pred 88. rojstnim dnevom (rojen je bil 1. julija 1926) je v Beogradu umrl profesor Dušan Savićević. Ker je bilo njegovo življenje in delo pomembno povezano z razvojem izobraževanja odraslih in andragogike tudi v Sloveniji, je prav, da se ga ob njegovi smrti spomnimo in ga spet predstavimo bralcem Andragoških spoznanj. ${ }^{1}$

V svojem življenju in na poklicni poti je prof. dr. Dušan Savićević opravljal številne vloge in dejavnosti, povezane z izobraževanjem in učenjem odraslih ter andragogiko. Kot osrednjo vlogo moramo označiti to, da je bil univerzitetni profesor za andragogiko na Filozofski fakulteti Univerze v Beogradu, bil je predstojnik katedre za andragogiko, ki jo je vodil z »očetovsko skrbjo za družinico«, ki jo je ustvaril in na katero je bil ponosen. Njegova zasluga je, da je imel Beograd kot prvi med univerzami nekdanje Jugoslavije samostojno in močno katedro za andragogiko, ki je štela več kot deset zaposlenih visokošolskih učiteljev. Svojim študentom ni bil le strog profesor, bil jim je na neki način tudi oče, saj ni skrival svojega veselja ob njihovih uspehih, ${ }^{2}$ tudi za študente je bil - tako kot za ožje sodelavce in osebne znance - »Duško«. Savićevićev mlajši sodelavec Miomir Despotović se je o svojem profesorju takole izrazil: ${ }^{3} \gg$ Skrbno nas je izbiral - kolikor se je moglo izbirati in izbrati. Ni nam, kot tudi ni sebi, niti malo prizanašal, česar mu ne bomo pozabili in tudi ne oprostili, posebno še, kadar je vztrajno iskal tudi tisto, česar ni mogoče niti dati niti narediti. Toda to, česar ne moremo pozabiti, je človeški in korekten osebni odnos do mlajših sodelavcev, ki jih - začenši že s prvim delovnim dnem - ni obravnaval kot svoje pomočnike pri študijskem in znanstvenem delu, temveč kot polnopravne sodelavce. Izkazoval jim je spoštovanje kot akademikom in osebnostim, ki si zaslužijo vso njegovo pozornost in spoštovanje.« $\mathrm{O}$ tem, kaj misli o svojih sodelavcih in kolektivu oddelka, je Savićević v intervjuju povedal:

»Znanosti ne sestavljajo posamezniki, kakršenkoli je že njihov prispevek k tej znanosti. Znanost ustvarjajo skupine ljudi, ki so ji predani in ki sprožajo zanimanje mladih za to znanost. $\ll^{4}$

1 Profesorja smo sicer v naši reviji že predstavljali, nazadnje leta 2006 ob njegovi 80-letnici (avtor Z. Jelenc).

2 Sam sem bil priča takemu veselju, ko mu je študent prinesel pokazati vezan izvod doktorske disertacije.

3 Na posvetu ob profesorjevi 80-letnici v Beogradu leta 2006.

4 Ta in vsi nadaljnji citati so iz intervjuja, objavljenega leta 2006 v Andragoških spoznanjih (avtor Z. Jelenc). 
Njegova druga prav tako pomembna vloga je bilo vodenje Inštituta za pedagogiko in andragogiko na Filozofski fakulteti Univerze v Beogradu. Med tem inštitutom in katedro je obstajala tesna povezava, kar je bila dobra podlaga za razvoj znanstvenoraziskovalnega dela osebja in študentov na fakulteti.

Navedeni vlogi in iz njih izhajajoče druge funkcije so profesorju Savićeviću omogočile, da je s sebi lastno prizadevnostjo in posvečenostjo ter vztrajnostjo razvijal andragogiko kot vedo in univerzitetno disciplino, s čimer je spodbudil pridobivanje novih in globljih spoznanj o izobraževanju in učenju odraslih ter postavljanje poglobljenih vprašanju na tem področju.

Na svoji več kot 60-letni poklicni poti se je najprej srečeval s prakso, ki je v začetku obsegala delovanje pri opismenjavanju odraslih, potem pa organiziranje dela ljudskih univerz, knjižnic, čitalnic ter poročanje o občinskih in okrajnih kulturnih dejavnostih. Sam pravi, da je bil »andragoški praktik v pravem pomenu te besede«. Kot že izkušen andragog se je odzval na razpis beograjske univerze za podiplomski študij in se opredelil za izobraževanje odraslih. Po končanem študiju je bil leta 1958 izbran za asistenta za izobraževanje odraslih in tako postal, kot je sam dejal, »prva plačana oseba v rednem delovnem razmerju na tem področju na univerzah tedanje Jugoslavije«. Njegova univerzitetna kariera na področju andragogike je postopoma rodila sadove, ki niso bili cenjeni le v Srbiji in Jugoslaviji, temveč so bili poznani v vsem svetu.

Pri strokovnem in znanstvenem delu so ga zanimala domala vsa področja andragogike - sam pravi, da je raziskovalno področje andragogike zelo obsežno -, a ocenjuje, da je največ pozornosti namenjal obči andragogiki, primerjalni andragogiki in proučevanju zgodovine andragoških idej. Obširno zanimanje Dušana Savićevića za vsa področja andragogike potrjujejo naslovi knjig, ki jih je objavil. Naj navedemo le nekatere:

- Uporaba metod v izobraževanju odraslih (Primena metoda u obrazovanju odraslih, Zagreb, 1961),

- Problemi integracije v izobraževanju odraslih (Problemi integracije u obrazovanju odraslih, Beograd, 1962),

- Izobraževanje za družinsko življenje (Obrazovanje za život u porodici, Beograd, 1967),

- Sistem izobraževanja odraslih v Jugoslaviji (The System of Adult Education in Yugoslavia, Syracuse, New York, 1968),

- Povratno izobraževanje (Povratno obrazovanje, Beograd, 1975),

- Človek in vseživljenjsko izobraževanje (Čovjek i doživotno obrazovanje, Titograd, 1983),

- Primerjalno raziskovanje izobraževanja in vzgoje (Komparativno proučavanje obrazovanja i vaspitanja, Beograd, 1984),

- Issues and Problems on Comparative Continuing Education of Adults (Madison, 1984),

- Koncepcija izobraževalnih potreb v andragogiki (Koncepcija obrazovnih potreba u andragogiji, Beograd, 1989), 
- Sodobno razumevanje andragogike (Savremena shvatanja andragogije, Beograd, 1991),

- Narava in značilnosti interesov $\mathrm{v}$ andragogiki (Priroda i karakteristike interesa u andragogiji, Beograd, 1992).

Pisanje in objavljanje knjižnih del je nadaljeval tudi po upokojitvi, ko je izdal še naslednja dela:

- Raziskovanje v pedagogiki in andragogiki (Istraživanja u pedagogiji i andragogiji, Beograd, 1995),

- Metodologija raziskovanja v vzgoji in izobraževanju (Metodologija istraživanja u vaspitanju i obrazovanju, Vranje, 1996),

- Izobraževanje odraslih: od prakse k teoriji (Adult Education: From Practice to Theory Building, Frankfurt, 1999),

- Korenine in razvoj andragoških idej (Koreni i razvoj andragoških ideja, Beograd, 2000),

- Pot k družbi učenja (Put ka društvu učenja, Beograd, 2000),

- Filozofski temelji andragogike (Filozofski osnovi andragogije, Beograd, 2002),

- Primerjalna andragogika (Komparativna andragogija, Beograd, 2003),

- Učenje in staranje (Učenje i starenje, Beograd, 2005),

- Andragoške ideje v mednarodnih okvirih (Andragoške ideje u međunarodnim okvirima, Beograd, 2006).

Savićević je bil prepričan, da »kamorkoli se obrnemo, ugotovimo potrebo po novih raziskovanjih, po novih znanjih o učenju in izobraževanju odraslih «. Seveda ne moremo na tem mestu naštevati vsega, kar je uspešno opravil profesor Savićević. Vodil je številne raziskovalne in razvojne projekte doma in $\mathrm{v}$ tujini, nastopal na nacionalnih in mednarodnih konferencah in srečanjih, sodeloval v pomembnh organih Unesca, OECD-ja in Sveta Evrope, bil član uredništev domačih in mednarodnih revij (npr. International Journal of Adult Education, Convergence, International Journal of Lifelong Education, Andragoške studije), bil gostujuči profesor na številnih tujih univerzah, obiskal andragoške ustanove na vseh kontinentih.

Delo in dosežki v okviru izobraževanja odraslih Dušana Savićevića uvrščajo med najvidnejše strokovnjake na področju andragogike v svetu. Tudi po njegovi zaslugi so andragogika iz nekdanje Jugoslavije in strokovnjaki na tem področju uživali velik ugled v svetu. ${ }^{5}$ Bil je sprejet v Mednarodno hišo slavnih na področju izobraževanja odraslih s sedežem v Oklahomi. Dobil je priznanja domačih (Srbija) in tujih vlad (Danska, Čile).

5 Če naštejemo nekaj najvidnejših, so to, poleg Savićevića: Borivoj Samolovčev, Dragomir Filipović (iz Srbije), Nikola Pastuović in Nikša Nikola Šoljan (iz Hrvaške), Ana Krajnc (iz Slovenije). A. Deleon je bil član Unescove skupine, ki je izvajala znani projekt »Learning to Be«. 
Poglede Dušana Savićevića lahko predstavimo še z nekaj njegovimi značilnimi razmišljanji.

O filozofski razsežnosti in vrednosti znanja ter izobraževanja:

»Boj za znanje bo v 21. stoletju hujši, kot je bil nekoč boj za ozemlja. Po nekaterih avtorjih je znanje vir moči. Znanje je še bolj nepravično razporejeno kot svetovno bogastvo.«

O izobraževanju z zornega kota gospodarske koristi in tržne logike ter trga dela:

»Filozofija, da je izobraževanje 'blago', ki mora zdržati konkurenco na trgu, vodi k temu, da se izobraževanje usmerja na globalni trg. V takšni filozofiji je izobraževanje 'blago', ki se prodaja v obliki kvalifikacij. Način razmišljanja s področja ekonomije se prenaša na področje znanja in učenja. To je mehanicističen pristop, ki ga ni mogoče sprejeti brez kritičnih pomislekov in proučevanja. Koncepcijo, da je izobraževanje blago in da se prodaja na trgu kot vsako drugo blago, je treba kritično premisliti, upoštevajoč filozofske in moralne razsežnosti učenja in izobraževanja. $\mathrm{S}$ takšnimi pojmovanji se prenaša ekonomska logika na filozofijo izobraževanja [...] Filozofija izobraževanja se mora razvijati mimo trga, potrošniške psihologije in psihologije posedovanja. Res je, da bo človek obvladal tehnologijo, toda vprašnje je, v čigavem interesu. Kako bo gledal na svet človek, ki nima zgrajenih splošnih vrednot in vrednotnega sistema? Filozofija trga razdira kulturno tradicijo in koncepcija globalizma spodbuja kulturno in tudi izobraževalno invazijo [...] Razume se, da širitvi znanja in znanosti ni mogoče postaviti meja, toda potreben je bolj uravnotežen model izmenjave znanja, potrebna je nova konceptualizacija učenja in izobraževanja, da bi lahko razumeli sodobni svet in v njem tudi 'tržno' usmerjenost znanja.«

O razvoju andragogike v svetu v prihodnjih desetletjih:

»Če presojam razvoj primerjalno, pričakujem v prihodnosti številne spremembe. Odprl se bo prostor za presojanje, prevrednotenje in znanstveno obdelavo še neobdelanih področij. Nastale bodo nove andragoške subdiscipline: andragoška futurologija, andragogika za varstvo življenjskega in delovnega okolja, visokoškolska andragogika, andragogika množičnih komunikacij, če naštejem samo nekatere. Od diferenciacije se bomo $\mathrm{v}$ andragogiki postopoma pomikali $\mathrm{k}$ andragoškim sintezam. Znanstvene sinteze so tisti element, ki bo dajal podlago andragogiki kot znanosti. Andragogika bo morala ustvarjati splošna znanja, ki jih bo mogoče uporabiti na posebnih področjih in pri subdisciplinah andragogike. Andragogika bo morala razumeti jezik filozofije, da bo lahko začela urejati terminološke zmede in da bo lahko odpravila pojmovne dvoumnosti ... Presojanje različnih paradigem $\mathrm{v}$ andragogiki zahteva temeljno filozofsko in metodološko izobraževanje bodočih teoretikov in raziskovalcev. Od tega bo odvisna tudi prihodnost andragogike.« 
Ni treba posebej navajati, kako povezan je bil Dušan Savićević s Slovenijo in kakšen vpliv je imel. Dovolj je, če vemo, da smo živeli v isti državi in da se je andragogika po vsej državi razvijala z medsebojnimi stiki in drugimi oblikami sodelovanja (programi, projekti, skupni nastopi v tujini itn.). Savićević je bil denimo vodja jugoslovanske delegacije na Unescovi konferenci o izobraževanju odraslih, ki je bila v Parizu leta 1985. Med andragogi iz republik nekdanje Jugoslavije so bili stalni stiki, med drugim tudi zaradi tega, ker so se republiška društva povezovala v Zvezo andragoških društev Jugoslavije.

Zoran Jelenc 